\title{
PERSONAL:
}

\section{MAPEANDO UMA NOVA PROFISSÃO NO MERCADO DE SERVIÇOS PESSOAIS.}

\author{
Maria Luisa Célia Escalona de Dios ${ }^{1}$
}

\section{Introdução}

O artigo trata da construção da oferta em um mercado de serviços pessoais e no seu bojo o surgimento de uma nova profissão a de personal. Os prestadores de serviço que atuam nesse mercado se anunciam como especialistas por deterem um conhecimento específico e se autointitulam de personal destacando a natureza individualizada dos serviços. O mercado de serviços pessoais é interessante porque ao mesmo tempo em que a relação entre o personal e o seu cliente é de proximidade para que o serviço possa ser personalizado, ela também é comercial. Dito de outro modo, no mercado personal se articulam duas lógicas, a das relações que criam vínculos e a lógica da racionalidade econômica. A constituição desse mercado é uma construção social que exige esforços, investimento de conhecimento, de criação de padrões, modulação do afeto, construção e manutenção de redes, ou seja, o que Zelizer (2009) nomeia de trabalho relacional. Portanto, dando a entender que a negociação entre personal e clientes exige esforço, é meticulosa e gradual, tendo em vista que os participantes da relação têm que se assegurar que as combinações são viáveis e as transações, veículos de troca e os limites estão adequados ao tipo de relação.

Parte deste texto integra a tese Chama o personal: estudo etnográfico sobre consultorias pessoais (Dios, 2017). O tema desta pesquisa se originou no final da dissertação de mestrado, na qual pesquisei ${ }^{2}$ os serviços ofertados por uma consultora de estilo ou, como ela mesma se denomina, personal stylist, e as demandas de cinco de

\footnotetext{
${ }^{1}$ Pontifícia Universidade Católica do Rio Grande do Sul, Brasil. Email: mldios@outlook.com ORCID id: https://orcid.org/0000-0002-0574-5525

${ }^{2}$ Dios, Maria Luísa Célia E. Com que roupa eu vou? Estudo etnográfico do processo de consultoria de estilo. Dissertação de mestrado. Antropologia. UFRGS, 2007.
}

Iluminuras, Porto Alegre, v. 21, n. 52, p. 119-158, abril, 2020. 
suas clientes ${ }^{3}$. Naquela ocasião, observei a crescente utilização, pelos clientes desta Personal Stylist, de diversos serviços oferecidos por outros consultores pessoais ou personals, como eles se autodenominam. Então, desde 2008 observo de forma empírica o mercado de serviços pessoais. Em 2013, no início do doutorado, através de um levantamento preliminar na mídia e da realização de entrevistas com usuários de serviços personals da minha rede de contatos pessoais, observei que, hoje em dia, a atividade das consultorias pessoais abrange quase todas as áreas da vida cotidiana. Assim, para cada contratempo é factível encontrar alguém propondo uma solução específica e sob medida, existindo, na internet, inúmeras ofertas destes profissionais. Eles oferecem seus serviços através de sites, vídeos, blogs e redes sociais. Existem personals para quase tudo: para ensinar a se vestir com elegância e cuidar da imagem pessoal; para ajudar a fazer atividades físicas e manter-se saudável; para auxiliar na elaboração do cardápio diário e ajudar a personalizar a dieta. Além disso, há personals que auxiliam nas compras, no preparo de jantares especiais e requintados. Há outros que levam cachorros para passear, outros, ainda, que auxiliam na elaboração de roteiros de viagem, fazem todas as reservas e aquisições de passagens, além dos que ensinam a paquerar, a ser sensual e "apimentar a relação", e os que auxiliam nos preparativos para a chegada do "pimpolho", ajudam no planejamento da aposentadoria, na escolha da carreira, na administração das finanças, na organização do guarda-roupa à geladeira, escritórios e, até os arquivos no computador. Há, também, ofertas de serviços pessoais para aconselhamento sentimental e para auxiliar na configuração de equipamentos eletrônicos.

No presente artigo busco compreender como se constrói a oferta por serviços pessoais a partir do mapeamento dessa nova profissão denominada de personal. Desta forma os seguintes questionamentos afloram: Como surge na sociedade brasileira a ideia de serviços personalizados - personal? Quais são as condições que tornaram possíveis o surgimento desta profissão? Como esses profissionais se legitimam no mercado? Procuro responder essas perguntas valendo-me de três caminhos: procurei compreender como se constrói essa oferta a partir do mapeamento dessa nova profissão denominada de personal por meio de um levantamento na mídia. Essa escolha se deu

\footnotetext{
${ }^{3}$ A consultora de estilo atendia clientes mulheres e homens, no entanto, para a dissertação, optei por fazer um recorte e pesquisar cinco clientes mulheres.
} 
pela falta de dados oficiais sobre os personals. Na sequência analiso o papel social exercido pelos personals recorrendo ao recurso conceitual de medidor cultural dos autores Pierre Bourdieu (2000), Gilberto Velho e Karina Kuschnir (2001). E por último busco compreender como se estrutura esse campo profissional pelo olhar de Boltanski (1982).

\section{Metodologia}

O texto faz parte de uma etnografia realizada em Porto Alegre e São Paulo entre 2013 e 2017 que teve como objeto de estudo um mercado de serviços pessoais (personal) que assumem a forma de consultorias. As pessoas que atuam na função personal não formam um grupo com limites delineados e claros. Então foi necessário abrir várias frentes de pesquisa para poder mapear este campo. As frentes de pesquisa foram os meios de comunicação: revistas, internet, programas de televisão e a minha própria rede de contatos. Estes meios produzem narrativas mobilizando o imaginário (Charaudeau, 2013 e Travancas, 2008), ou seja, o conjunto de imagens - narrativas, fotografias, programas de televisão, etc. - da profíssão de personal. Esse imaginário, construído por estas mídias, coloca o serviço de personal como objeto de consumo, característica de classe e signo de status, conforme descrito abaixo.

Por meio dela contatei dezoito personals dos mais variados tipos, sendo que com seis deles, tive a oportunidade de desenvolver a observação, entrevistas semiestruturadas e convivência de longa duração. Embora o número de personals pesquisados possa parecer excessivo para uma etnografia, essa quantidade possibilitou que eu obtivesse um bom mapeamento desse campo profissional.

Os seis personals com os quais tive acesso mais profundo e longo foram: Dora personal organizer (especialista em organização de ambientes), Marta personal stylist (especialista em consultoria de estilo), Amadeu personal dog walker (cuidador e passeador de cachorros), Eduardo personal trainer (especialista e professor particular de educação física), Madalena personal friend (acompanhante de senhoras para eventos sociais, nos quais assume o papel de amiga de longa data) e Alexandre personal xamã (guru ou guia espiritual). Por sua vez, com os outros doze personals citados no texto tive um acesso apenas a informações pontuais, obtidas através de um acompanhamento breve e de entrevistas. A etnografia com os clientes dos personals aqui apresentados está calcada na possibilidade de acesso. Foram três Narjara, Luan e Francisco. Os 
serviços de personals que eles utilizavam de forma semanal ou diária eram: personal asistent, personal dogwalker, personal diet, personal shopper, personal xamã, personal trainer, personal friend, personal dancer. Já os serviços como personal stylist, personal décor, personal organizer, personal invest, personal turist agent, personal DJ, personal husband e personal car são utilizados de maneira mais esporádica, isto é, de duas a quatro vezes por ano. Devido às horas dedicadas ao trabalho (10 a 12 horas por dia) e a suas viagens frequentes tornou-se complexo realizar a etnografia, consegui acompanhálos de 2013 a meados de 2015. No apêndice A apresento uma visão geral do tipo de profissional que consegui acessar com breve perfil de cada um deles e dos três clientes, mais informações a respeito deles serão fornecidas ao longo do artigo. Os nomes dos interlocutores foram alterados para preservar as suas identidades.

\section{O olhar da mídia}

A primeira questão com a qual me deparei foi a inexistência de estatísticas oficiais nas quais a atividade profissional identificada como personal pudesse ser dimensionada. Porém essa atividade era visível em incontáveis reportagens de revistas, jornais e programas de TV, bem como no imaginário da população, em especial o personal trainer, que foi o pioneiro, e os personals stylist e organizer, que são os mais populares devido a sua intensa difusão na televisão. Ao mesmo tempo, quando se conversava sobre os personals com pessoas, das mais variadas trajetórias e estratos sociais, elas reconheciam a respeito do que se estava falando e se entusiasmavam com o tema, como se a categoria personal fosse autoevidente e existisse desde sempre.

\section{Revistas: Veja, Exame e Cláudia ${ }^{4}$}

$\mathrm{Na}$ Veja, a palavra personal apareceu pela primeira vez numa reportagem em 1971 denominando um serviço bancário no Citi Bank, o Personal Bank, $e$ as reportagens sobre os profissionais que se denominam personal surgem no final da década de 1990. Na Exame, as reportagens sobre esta atividade apareceram

\footnotetext{
${ }^{4}$ Optei por pesquisar essas revistas, pois todas as edições encontram-se online e são de grande circulação.
} 
esporadicamente, somente, em meados da década de 2000 e, na Cláudia, somente duas reportagens em 2011 foram encontradas.

Durante as décadas de 70, 80, e até meados dos anos 90, o termo personal apareceu na revista Veja associado às áreas financeira e tecnológica. Quando a palavra personal aparecia relacionada a algum serviço financeiro, ela tinha a conotação de especial, exclusivo e pessoal. Por sua vez, quando a o termo personal estava vinculado à área tecnológica, especialmente, em anúncios de aparelhos eletrônicos ${ }^{5}$, os anúncios davam a entender que, possuir um eletroeletrônico com uma programação que poderia ser personalizada pelo usuário, através da tecla personal ou possuir um PC (personal computer), ou seja, aderir às novas tecnologias conferia status e distinção ao proprietário. Em suma, o termo personal começava a ser, paulatinamente, relacionado a conceitos de exclusividade, inovação tecnológica, sob medida, êxito social e profissional. Entre os anos de 1997 e 2013 apareciam com certa frequência reportagens sobre os personals, nomeados pela Veja como profissão; desde 2014 em diante o número de reportagens sobre eles caiu drasticamente.

Os primeiros a aparecer foram os personal trainers e a utilização desse serviço estava atrelada a indivíduos com trajetórias ascendentes, como celebridades, artistas, atletas, políticos ${ }^{6}$ e empresários. Nessas reportagens, os personal trainers eram o assunto principal ou davam a sua opinião como experts em temas sobre saúde, beleza, alimentação, bem-estar, imagem pessoal/profissional, carreiras, entre outros. Em vez de entrevistarem médicos, nutricionistas, psicólogos, as reportagens traziam as opiniões de personal trainers, que apesar de serem graduados em Educação Física, não tinham formação acadêmica específica nos temas abordados nas reportagens. Nesse contexto, o crescimento de exposição dos personal trainers pode ser tomado como indicativo do aumento de prestígio da profissão, no período. Também nessa época, apareceram várias reportagens (embora em menor número) sobre outros tipos de personals, como stylist, organizer, diet, sex trainer, dog, cook, gourmet, também como prestadores de serviços de atores sociais com trajetórias ascendentes. O conteúdo das reportagens enfatizava a melhoria de vida das pessoas que contratavam esse tipo de consultoria pessoal e especializada. Burilar a aparência com a ajuda de um personal stylist; ter um físico

\footnotetext{
${ }^{5}$ Exemplos dos eletroeletrônicos anunciados: Mini TV Personal View LCD, Personal Computer (PC), TV TrendSet, ET Personal 50.

${ }^{6}$ Nova elite política, principalmente, do PT.
} 
esculpido pelos personals trainers; ser saudável como resultado de cardápios elaborados por um personal diet; ter a vida organizada por um personal organizer e oferecer um jantar aos amigos feito por um personal chef, de acordo com as reportagens todos estes são sinais de competência, sucesso profissional e distinção social.

Na revista Exame, a partir de 2003, foram veiculadas reportagens sobre certos tipos de personals como: personal financial planing, personal assistent, personal art, personal chef/gourmet, personal somelier/winer, personal diet e personal invest, e ela os trata como uma nova ocupação. O foco das matérias é o indivíduo que se tornou personal. As reportagens indicavam que os atuais personals trabalhavam como executivos ou em áreas técnicas e que transformaram sua experiência e o conhecimento, adquiridos ao longo dos anos em serviço especializado e personalizado; ou que transformaram o hobby em profissão. Nessas publicações destacava-se que os executivos, agora personals, eram oriundos de universidades renomadas ${ }^{7}$ e tinham variadas formações, tais como: Administração, Contábeis, Engenharia, Medicina, Nutrição, Advocacia, Arquitetura, Belas Artes, Agronomia. Os que atuavam como personal art advisor e personal winer, além de serem graduados em universidades reconhecidas, vinham de famílias tradicionais, nas quais desde tenra idade cultivava-se, via aprendizagem familiar, a apreciação pela arte e pelo vinho. Nas entrelinhas das reportagens constata-se que estes indivíduos são oriundos de extratos sociais economicamente favorecidos e que encontraram espaços profissionais em que eles puderam converter suas aptidões e talentos em capital econômico (Bourdieu, 2000; 2005).

A Revista Casa Claudia publicou em 2011 duas reportagens com personal organizers. Elas são denominadas "verdadeiras governantas contemporâneas", organizando armários, geladeiras, guarda-roupas, home offices ${ }^{8}$ e escritórios, além de também treinarem os empregados para que eles mantenham a organização conforme as regras determinadas por essas especialistas.

\section{Televisão}

$\mathrm{Na}$ televisão brasileira, os personals começaram a ser mencionados nos programas dos canais internacionais a cabo, em 2004, no programa britânico sobre

\footnotetext{
${ }^{7}$ Como USP, UFRJ, Ufrgs, UNB, Mackenzie, PUC/Rio, PUC/SP, Unesp.
}

${ }^{8}$ Escritório dentro de casa. 
consultoria de estilo, denominado What not wear, que no Brasil recebeu o nome de Esquadrão da Moda e começou a ser transmitido numa versão brasileira em 2009. Posteriormente, esse tipo de programa disseminou-se em esquetes por outros canais a cabo brasileiros. Esses programas tinham o objetivo de provar que toda mulher pode estar bem vestida, em todas as ocasiões, adotando os critérios indicados pelos personals Stylists. O cabelo e a maquiagem mereciam, também, especial cuidado no conjunto da indumentária. Na mesma época, começaram a ser transmitidos pelos mesmos canais a cabo programas de organização de ambientes, que seguiam a mesma linha. Uma personal organizer (consultora em organização de ambientes) com sua equipe visitavam a casa e realizavam o trabalho de organização dos cômodos da residência. Na TV a cabo internacional, o programa se intitulava Cada coisa em seu lugar. No Brasil, esses programas começaram a adquirir notoriedade em 2011, com o programa Santa Ajuda (GNT) e Consultoria do Lar (SBT). Depois de 2012, começam a aparecer programas com o mesmo feitio, porém mudando o tipo de profissional, e assim temos programas com personal chefs, personal diets, personal trainers, alguns deles não passando da primeira temporada. Em 2016, os programas que ainda continuavam a ser produzidos eram os de consultoria de estilo e de organização de ambientes, por razões de audiência e por atrair um maior número de patrocinadores, pela variedade de produtos que neles podiam ser exibidos. $^{9}$

Nas novelas veiculadas, principalmente depois de 2006, apareceram personagens que atuavam como personals oriundos de famílias tradicionais falidas e que auxiliavam personagens em ascensão social em questões relacionadas ao comportamento, etiqueta e estilo de vestir. Nos programas de humor também começaram a surgir menções e piadas relacionadas aos personals. O mais marcante foi um quadro do programa Zorra Total ${ }^{10}$, cuja protagonista Lady Kate era uma "emergente" (nova rica) carioca que sempre estava acompanhada pelo seu personal stylist. Os personals que aparecem nas novelas provêm de famílias tradicionais que outrora foram abastadas e detêm capitais como saber se vestir com estilo, etiqueta, apreciar arte, ou seja, capitais simbólicos, que, através da atividade de personal, encontram um meio para serem reconvertidos em capital

\footnotetext{
${ }^{9}$ No caso dos programas de organização de ambientes, os patrocinadores são lojas de bricolagem, de produtos de decoração, de artigos para organização doméstica, de material de construção, de móveis, de reforma de móveis, etc. Nos programas de estilo, os patrocinadores são grandes redes de lojas de roupa, marcas conhecidas de produtos de beleza.

${ }^{10}$ Programa humorístico brasileiro produzido e veiculado pela Rede Globo de Televisão, aos sábados à noite, exibido entre 1999 a 2015. www.memorariaglobo.globo.com. Acessado em 06 de jan., 2014.
} 
econômico (Bourdieu, 2000; Saint-Martin, 1995). O aparecimento do personal como personagem de novela e de programas cômicos mostra a difusão e o aumento de prestígio desses profissionais na sociedade brasileira. Também indica que o público se interessa por observar, por consumir a imagem desse serviço, e não por consumi-lo, tendo em vista, que esse tipo de serviço é restrito a uma condição de classe.

Finalizando a análise, a Revista Veja destaca mais os usuários dos personals, salientando que são indivíduos que ascenderam socialmente. Na Exame, constata-se que os indivíduos que se tornaram personals encontraram espaços profissionais onde puderam converter seus talentos em capital econômico. As matérias veiculadas pela revista Cláudia seguiam a mesma linha da Exame, destacando como mulheres acima dos quarenta anos, com experiência de vida, curso superior, e outras que sempre foram donas de casa, encontraram uma maneira de valorizar suas habilidades e convertê-las em capital econômico, tornando-se personal organizers ou especialistas em organização. $\mathrm{O}$ argumento comum em todas as reportagens era de que os personals eram profissionais essenciais para manter o estilo dos clientes. Em suma, a mídia destaca os benéficos de se contratar um personal, que os clientes são pessoas que acenderam socialmente, e que tornar-se personal é uma nova e rentável oportunidade no mercado de trabalho, tendo em vista que o investimento seria baixo, ou seja, que bastava transformar talentos, habilidades ou conhecimento em serviços.

\section{Campo dos mediadores culturais}

Nesta parte apresenta-se o papel social dos personals como mediadores culturais, pelas perspectivas de Pierre Bourdieu (2000) e Karina Kuschnir e Gilberto Velho (2001), que são muito similares. Os mediadores culturais têm a capacidade de lidar com vários códigos e transitar por universos sociais distintos, criando passagens entre eles. De acordo com Velho e Kuschnir (2001:9) o estudo dos mediadores é relevante, pois permite constatar como se dão as interações entre categorias sociais e níveis culturais distintos.

Bourdieu (2000) desenvolveu a noção de mediador cultural ou intermediário cultural com o intuito de caracterizar aqueles atores sociais que fornecem produtos e 
serviços simbólicos, a saber, estilos de vida, imagens, status. A disseminação da noção bourdiana de mediadores culturais foi central em vários trabalhos acadêmicos para entender o significado dos entrelaçamentos entre a produção e o consumo. Bourdieu (2000:138) argumenta que esses atores sociais possuem "profissões ambíguas" ligadas aos meios de comunicação, publicidade, design, comércio de antiguidades, de objetos considerados exóticos e rústicos, também, comercio de vestuário e artigos que estão na moda. O autor considera que estas profissões são ambíguas por dois motivos. O primeiro porque a competência técnica conta menos que a tradição familiar, que o pertencimento a uma classe dominante e que o domínio de signos do que é considerado bom gosto e requinte. Os mediadores culturais são atores sociais que reconvertem capitais. Assim, os diversos capitais adquiridos no convívio familiar e no pertencimento a um determinado meio social lhes conferem certa herança cultural que pode ser transformada em capital econômico, uma vez que não obtiveram êxito no ensino formal. (Bourdieu, 2000:140). O segundo é devido ao fato de que na classificação das categorias socioprofissionais ${ }^{11}$ do INSEE $^{12}$, essas ocupações estavam definidas de forma muito vaga e algumas ainda não estavam contempladas, na época em que o autor utilizou as informações ali contidas para realizar a sua pesquisa sobre o gosto. Estas são ocupações que são definidas por seu papel na mediação entre a produção e o consumo. Conforme Bourdieu (2000), os "mediadores culturais" são especializados na orientação e na imposição social do gosto ou, como ele os denomina, taste-makers (Bourdieu, 2000:312). As opiniões destes têm o poder de legitimar ou deslegitimar práticas, comportamentos culturais e gostos.

A legitimidade dos mediadores culturais não está calcada na autoridade acadêmica e racional de profissões tradicionais (Medicina e Direito), nem na autoridade vinculada ao estado. Os mediadores culturais utilizam a aparência, as atitudes e as imagens para legitimar suas recomendações e exercer influência sobre os outros. Eles acreditam no seu valor e no valor dos seus serviços. A assim, vendem-se a si próprios como modelos a serem seguidos e, também, como garantia dos serviços prestados; isso

\footnotetext{
${ }^{11}$ Categorias socioprofissionais: nomenclatura complexa desenvolvida e utilizada pelo governo francês para estudar a estrutura social e compreender melhor o estilo de vida francês. Ela foi elaborada tomando como referências as profissões, a qualificação, a hierarquia na área de atuação e o setor.

12 INSEE: Institut national de la statistique et des étudies économique, que é o órgão público francês de estatística e estudos econômicos, semelhante ao IBGE.
} 
lhes dá margem para uma imposición simultaneamente más violenta y más dulce (Bourdieu, 2000: 369), ou seja, lhes confere autoridade simbólica.

A noção de mediadores cultutrais na concepção de Bourdieu (2000), de Velho e Kuschnir (2001), além de ser similar é muito inclusiva e abrangente, abarcando uma miríade de atores sociais que têm ocupações muito variadas, além de trajetórias acadêmicas e sociais diversas, que guardam similaridades com a categoria personal que é aqui investigada. Assim, a referia noção se mostra interessante para refletir sobre o ofício personal na sociedade brasileira, pois podem ser entendidos como mediadores culturais, tendo a capacidade de lidar com vários códigos e transitar por universos sociais distintos, criando passagens entre eles.

Assim como os mediadores culturais, os personals vendem serviços simbólicos, a saber, estilos de vida, experiências, positivação social, comportamento, status e imagens (Bourdieu, 2000). Eles, também, são detentores de recursos ou capitais (social, cultural, político, econômico e simbólico), sendo alguns personals mais hábeis que outros para combinar as formas de recursos disponíveis para convertê-los em trunfos e posteriormente em capital econômico, como demonstram as falas dos clientes de Marta (personal stylist), Eduardo (personal trainer) e Dora (personal organizer):

Pra mim, a Marta é o máximo das personals stylist, o estilo dela vem de berço, a gente vê pelo jeito charmoso dela combinar as roupas, andar e falar [...] que tem estirpe [...]. e isso ninguém consegue imitar e, mais ainda, ela tem vocação pra coisa... tipo professor e padre [...] a sina dela é deixar um rastro de elegância por onde passa. A Marta nunca precisou fazer curso de personal stylist no Senac, ela já nasceu sabendo, por isso eu pago, vale a pena. Se é para ter uma personal daquelas fajutas que fazem curso de personal stylist no Senac, ou que fez um curso por aí [...] sabe? daqueles que tem aos montes em São Paulo [...] ou comprou livros de estilo na Saraiva e na Cultura e assiste o H\&H e o GNT...não gasto dinheiro, né? Isso eu mesmo faço, né? A Marta tem inovação nas combinações de cores e roupas, ela mistura roupas que eu nem penso em misturar e que também não vejo nas revistas de moda, isso é natural dela, vem de dentro. Depois que ela revolucionou meu guarda-roupa, elaborou meus looks, nunca mais fui a mesma, me sinto sempre andando no tapete vermelho. O máximo! (Narjara, cliente da personal stylist Marta).

O Eduardo é muito mais que um personal trainer, também né, tá no sangue, família de médicos, o guri já saiu pronto do berço [...] por isso não acho caro [...] ele tem muito conhecimento, e quando ele vem com uma novidade, eu aceito, confio, sei que ele faz o melhor, assim como o pai e os tios. (Luan, cliente de Eduardo, personal trainer).

A Dora já nasceu com vocação para beleza e organização, toda a família dela é assim, desde sempre trabalhando com decoração [...] ela já faz isso há muito tempo, muito antes da Micaela Góes do Santa Ajuda, ela é original, tem seus métodos que agora estão copiando; ela cria na hora, ela tem talento para organizar as coisas do jeito da gente, ela organiza com beleza e praticidade, isso não se encontra em 
programas de TV, palestras ou livros, vem de dentro da pessoa. (Francisco, cliente de Dora, personal organizer).

Dependendo da área de atuação do personal, seu êxito oscilará entre a familiaridade da cultura de classe e o controle dos signos e emblemas da distinção e gosto que da competência técnica (Bourdieu, 2000:138,139).

O campo dos personals entendidos como "mediadores culturais" é um espaço estruturado dentro do campo de setor de serviços. O campo personal é composto por diferentes tipos de personals, ou seja, não é homogêneo. Ele é um lugar de confrontos onde os personals de cada tipo disputam entre si o acesso aos capitais que são valorizados no campo que é analisado a seguir.

\section{A estruturação do campo profissional personal}

Nesta parte evidencia-se como se estruturou o campo profissional dos personals por meio das origens das suas trajetórias e a imagem de si tendo como aporte teórico Luc Boltanski (1982). Em seu estudo sobre os cadres (executivos), Luc Boltanski (1982) deparou-se com uma categoria ambígua e muito diversificada. O autor constatou que, além dos cadres formarem um grupo fluido, sem limites e também sem critérios de pertencimento e exclusão claros, alguns sentiam que eram considerados pelos pares como exemplos de cadres exitosos. Assim, para analisar o grupo, o autor leva em conta qual imagem que seus interlocutores possuem de si mesmos, utilizando-a para definilos. Dessa forma, ele utiliza as categorias empregadas pelos próprios informantes.

Boltanski (1982) entende que existe uma homologia entre as categorias mentais dos pesquisados e a estrutura social do grupo. Contudo ele enfatizou que a palavra categoria ou grupo não seria utilizada como se ela fosse homogênea, mas no sentido conferido por Eleanor Rosch (Boltanski, 1982:464). Os trabalhos interdisciplinares ${ }^{13}$ dessa autora mostram que as taxionomias populares ou categorizações práticas, ou seja, aquelas utilizadas pelos sujeitos pesquisados, distam de constituir ordenamentos uniformes ou categorias separadas por limites nítidos ou por critérios claramente definidos; ao contrário das classificações regularmente utilizadas na área acadêmica. Eleonor Rosh (Boltanski, 1982:465,466) defende que cada categoria mental é

\footnotetext{
${ }^{13}$ Antropologia, ciências cognitivas e psicologia social.
} 
organizada ao redor de um significado central, formado pelo exemplo emblemático, isto é, aquele que melhor exemplifica as propriedades da categoria. Ao redor desses casos, considerados pelos informantes os melhores exemplos, agrupam-se outros casos ou membros dessa categoria, em ordem decrescente de semelhança em relação ao exemplo paradigmático.

Conforme descrito por Boltanski (1982), a referida teoria foi testada por Rosh em diversas áreas de estudos, como na percepção de cores, formas e, também no estudo da percepção da categoria "cachorro" (pesquisas feitas nos EUA). Na pesquisa sobre percepção das cores, ela detectou, através das respostas dos pesquisados, que existem vermelhos percebidos como mais vermelhos que outros. Por sua vez, ao estudar a categoria "cachorro", Rosh descobriu que, embora os sujeitos pesquisados fossem escolarizados e conhecessem a classificação zoológica do reino animal, na percepção dos americanos existem cachorros que são considerados mais cachorros do que outros (more doggy than others). Então, quando solicitados espontaneamente a pensar na categoria "cachorros" em geral, os pesquisados pensavam na raça retrivers como um bom exemplo de cachorro, ao passo que os cachorros da raça pequinês foram considerados um mau exemplo de cachorro. E ela também percebeu que, entre a raça retriver e a raça pequinês, existe muita imprecisão entre as classificações feitas pelos pesquisados, o que mostra, segundo a autora, que a imprecisão é inerente a esse tipo de classificação.

Ao pesquisar o processo de formação de um grupo social - les cadres -, Boltanski (1982) também constatou que eles se percebiam dispostos ao redor de um núcleo central (o cadre considerado como um exemplo emblemático), não existindo fronteiras precisas, nem critérios claros de pertencimento, levando-o a perceber o conjunto dos cadres como um grupo social fluido.

\section{Personal: a formação de uma "categoria profissional" 14}

A abordagem de Boltanski (1982) auxiliou-me a perceber como os informantes percebiam-se reciprocamente. Assim, pensa-se que os postulados de Rosch, utilizados por Boltanski (1982), também podem ser trazidos para refletir sobre como os personals

\footnotetext{
${ }^{14}$ Inspirado no título do livro de Luc Boltanski,1982, Les cadres: La formation d'un groupe social.
} 
se percebem, pois pude observar que eles se pensam de modo similar ao grupo pesquisado por Boltanski (1982). Em outros termos, depreendi que os personals pesquisados também se percebem dispostos ao redor do que eles percebem como um bom exemplo de personal ou um personal "bem-sucedido", o que será demonstrado e analisado a seguir.

Desta maneira, inferi que alguns dos interlocutores almejam ser bem-sucedidos e, conforme se constatou, esforçando-se muito para isso, tinham em mente exemplos claros do que eles consideram um personal exemplar (paradigmático), e os designavam por meio de expressões como: "personal de verdade", e a mais verbalizada "personal bem- sucedido". Seguem algumas falas desses interlocutores que evidenciam a questão:

[...] a minha meta é ser uma Micaéla Goes (personal organizer que apresenta o programa de TV Santa Ajuda ${ }^{15}$ ), ela sim que é a verdadeira personal organizer, um super exemplo de sucesso [...] um dia ainda chego lá [...] mas sem programa de TV, aí já é demais, né? Tô na batalha [...] já fiz vários cursos da $\mathrm{OZ}{ }^{16}$, mas o começo é sempre difícil[...]gaúcho é muito resistente a novidades[...] (Eugênia, graduada em Tecnologia de Gestão da Qualidade, Uniasselvi/IERGS, aspirante a personal organizer bem-sucedida).

[...] o meu objetivo profissional é ser como o preparador físico Nuno Cobra. [...] me esforço muito para isso, procuro ser um exemplo para meus alunos como ele foi para o Airton Senna. [...] é dureza, mas sei que vai compensar tanto trabalho[...]ele ( Nuno Cobra) foi e continua sendo uma grande inspiração, embora, às vezes, seja mal compreendido por alguns da profissão e pelos críticos que falaram mal do livro dele. Ele é daqueles que se dão bem na profissão, bem-sucedido, os que criticam ele [...]é pura inveja, se criticam é que chegou lá, né?(Pedro, 36 anos, formado em Educação Física, Unilasalle, aspirante a ser personal trainer bem-sucedido).

Por sua vez, os que têm consciência do seu sucesso e são assim percebidos se concebem como os mais legítimos do ramo e explicitam, claramente, seu incômodo com os que atuam na atividade de personal de forma transitória, deste modo, denominando-os de "oportunistas" ou "aventureiros". Seguem algumas falas desses interlocutores que evidenciam a maneira pela qual eles, que já estão estabelecidos, se percebem em relação aos outros:

Hoje em dia tem muito aventureiro na profissão de personal trainer, saem da faculdade com diplominha na mão e vão trabalhar em qualquer academia como personals. Eles não têm ideia da quantidade de cursos que fiz e quanto trabalho passei para ser bem-sucedido na minha profissão. (Eduardo, personal trainer bemsucedido).

\footnotetext{
${ }^{15}$ Programa veiculado pelo canal de televisão a cabo ( paga) GNT.

${ }^{16}$ Empresa que vende cursos online de organização. OZ Cursos. www.organizeasuavida.com.br.
} 
De uns tempos pra cá virou chique ser personal organizer, faz um cursinho na OZ, participa da palestra da Micaéla e assiste o Santa Ajuda e se acha a tal (Dora, personal organizer bem-sucedida).

Essa garotada faz um curso de moda e quando se forma já faz cartão de visita, blog de estilo e tendências de rua para serem personal stylist, sem conteúdo e sem experiência. E ainda tem a ousadia de me ligar ou me contatar por e-mail pedindo para serem estagiárias ou assistentes, dizendo que admiram meu trabalho. Elas só querem aprender e depois viram minhas concorrentes (Marta, personal stylist bemsucedida).

Também pude constatar que os personals que se consideram legítimos por atuarem a mais tempo e terem seu sucesso reconhecido publicamente denominam de "aspirantes" aqueles personals que almejam ser "bem-sucedidos" e reconhecem o valor da atividade de personal, e também a enxergam como um meio de vida e realização profissional. Como exemplos dessas falas temos:

Tu sabe que recebo muitos e-mails de gente que quer atuar na área e acha que eu tenho a receita de bolo do sucesso, esses eu nem dou a mínima[...] ]em compensação tem uns poucos que entram de cabeça na profissão, largam emprego, criam site, blog, estudam para se dedicar à profissão de personal trainers, por esses aspirantes tenho o maior respeito, eles são sérios[...] eles chegam a trabalhar como empregados e, à noite, se dedicam na atividade de personal, se puxam. Um dia chegam lá. (Eduardo, personal trainer bem-sucedido).

[...] esses dias me emocionei [...] tava com uma cliente no shopping e uma funcionária da Zara veio conversar comigo e dizer que eu era a inspiração dela, ela estava estudando Design de Moda e queria ser personal stylist, inclusive ela me falou que trabalhava como personal nos finais de semana. Falei para minha cliente: essa aspirante vai longe, ela sabe o que quer, se esforça e nem fez questão de se encostar em mim, educada e sabe reconhecer sem querer se aproveitar, vai longe. (Marta, personal stylist bem-sucedida).

Na sequência seguem relatos de interlocutores que atuam na atividade personal de forma provisória - que são denominados tanto pelos "bem-sucedidos" como pelos "aspirantes" de "oportunistas" ou "aventureiros" 17 - e que enxergam a atividade de personal como um meio de entrar no mercado de trabalho, tecer uma rede de relações

17 Outros autores também discutiram rótulos internos para uma mesma profissão ou ocupação como Howard Becker (2012:67) quando aborda como os músicos de jazz se classificam de acordo com "o grau em que cedem aos outsiders (proprietários de casas noturnas e clientes); o continuum varia desde o músico de "jazz", num extremo, até o músico "comercial", no outro". Outra classificação dos músicos é em relação ao seu sistema de crenças. Eles se concebem como criativos, com dom natural para a música que não pode ser adquirido por estudo, dotados de comportamento inusitado e que não seguem regras e denominam de "quadrados", o público em geral, ou seja, aqueles que não são músicos (Becker, 2014:69). Alba Zaluar (1994) na sua etnografia sobre a Cidade de Deus interpreta no caso das classes populares as diferenças que os sujeitos fazem entre "trabalhadores" e "bandidos". Na pesquisa de Maria Dulce Gaspar (1988:91) sobre garotas de programa ela identifica como as prostitutas se auto classificam conforme o local, horário de trabalho e em relação aos agenciadores dos programas. 
pessoais, para depois conseguir um trabalho mais estável (significando trabalhar com carteira assinada ou emprego público) ou que tenha mais chances de desenvolvimento profissional no futuro (no sentido de uma carreira em que possam ser promovidos), segundo estes:

Por enquanto trabalho como personal trainer em duas academias [...] por enquanto isso é só uma passagem [...] desse jeito estou conhecendo um monte de gente, mas se conseguir entrar no mestrado da UFRGS, com bolsa, ou passar em concurso largo essa parada [...] a bolsa é uma mixaria, mas já garanto um fixo e junto com o trabalho de personal o mês fica mais folgado[...] com mestrado tenho futuro e, se não, como concursado tenho emprego a vida toda, sem crise. Por que Marcio Atalla só um em cada mil anos, né? (Felipe, 25 anos, formado em Educação Física, Univates, atua como personal trainer de forma temporária).

Meu marido foi transferido para Porto Alegre, tá difícil me empregar na minha área e, enquanto não passo num concurso, a melhor opção foi fazer os cursos da $\mathrm{OZ}$ e trabalhar como personal organizer, afinal sempre fui obcecada por organização como a Micaéla, do Santa Ajuda, ela é meu exemplo, mas tá difícil esse início. Então vou levando enquanto estudo pro concurso. Ainda tenho a esperança de ganhar algum dinheiro como personal organizer, mas não quero isso pro resto da vida (Renata, 32 anos, formada em Direito, Anhanguera/Santo André, que está na atividade personal organizer de forma provisória).

As falas acima denotam que alguns interlocutores "são", isto é, se concebem personals, a saber, os "bem-sucedidos" e os "aspirantes". Já outros "estão" personals, encarando o ofício de modo transitório, que são os "aventureiros" ou "oportunistas". No entanto, os relatos explicitam que, tanto os "aspirantes" como os "aventureiros" ou "oportunistas", têm uma referência do que eles julgam ser exemplos emblemáticos, ou seja, os "bem-sucedidos", o modelo do que eles entendem como um personal legítimo (verdadeiro), um exemplo a ser seguido, conforme relato dos informantes.

O argumento teórico de Boltanski (1982) de que a formação de um grupo é subjetiva, e não objetiva, e de que este pode se formar em torno de uma ideia de si mesmo, por meio da definição de credenciais educacionais e tarefas profissionais de seus membros, redirecionou o meu olhar sobre a categoria personal, fazendo com que ela enfatizasse nuances que antes tinham passado despercebidas. Então, o que parecia ser um grupo heterogêneo e impreciso, como uma nebulosa, curiosamente, começou a tomar forma. Assim, dentro da nebulosa, comecei a vislumbrar um sistema planetário cujos corpos celestes espalhavam-se em três órbitas principais. Uma órbita central, na qual se situam as representações dominantes relativas aos vários tipos de personals (trainers, stylist, organizer, etc.); a órbita secundária, em que se posicionam os personals que almejam às representações dominantes e, por último, a órbita periférica, 
na qual se localizam aqueles indivíduos que atuam no oficio de personal de forma transitória. Inspirada nos termos que aparecem nas falas dos informantes, denominei cada uma dessas instâncias da seguinte maneira: os "bem-sucedidos", os "aspirantes", e os "aventureiros" ou "oportunistas". Desta forma voltando ao exemplo da categoria "cachorro", estudada por Rosh (appud Boltanski, 1982) ter-se-ia que os personals que se encontram na órbita interna - "bem-sucedidos"- são equivalentes aos cães retrivers, e os que se enquadram na órbita externa - "aventureiros/oportunistas"- assemelham-se aos cachorros da raça pequinês. Já os "aspirantes" situam-se numa órbita intermediária, entre os "bem-sucedidos" e os "aventureiros", que se caracteriza pela sua quantidade, diversidade e imprecisão.

\section{"Bem-sucedidos"}

Cinco dos informantes, a saber, Alexandre (personal xamã), Eduardo (personal trainer), Dora (personal organizer) e Marta (personal stylist) e Amadeu, (personal dog walker ) se enquadram nas representações dominantes, exemplos emblemáticos do que seria um "verdadeiro personal", ou seja, eles são reconhecidos pelos outros personals pesquisados como "bem-sucedidos". Analisando por meio de convívio cotidiano e de longa duração pude perceber nos relatos desses cinco informantes que alguns aspectos se destacavam e eram comuns entre eles, embora atuassem em atividades distintas. São eles:

- A quantidade dos personals bem-sucedidos é reduzida, em relação aos informantes pesquisados.

- Eles têm densa e ampla rede de relações pessoais e familiar (sobrenome tido como tradicional ou reconhecido socialmente), a qual recorrem para estar continuamente amealhando novos trabalhos. As redes dos cinco informantes tidos como exemplos paradigmáticos incluem políticos, profissionais dos meios de comunicação, empresários de médias e grandes empresas. São oriundos de camadas sociais privilegiadas, em que as famílias são proprietárias de médias e grandes empresas, tanto na área da indústria, como comercio, serviços e rural.

- Para os "bem-sucedidos", o oficio de personal é mais uma fonte de renda, como demonstram os depoimentos: "como poderia me dedicar a meus clientes tendo 
preocupações financeiras" (Dora, personal organizer) e "impossível trabalhar como personal tendo que ao mesmo tempo vender os meus serviços" (Eduardo, personal trainer). A renda com a qual se sustentam tem origem nas mais variadas fontes, tais como: aposentadoria agregada de rendimentos de planos de aposentadoria, pensões, renda do cônjuge (diretor de empresa ou funcionário publico federal ou estadual de alto escalão), dividendos de empresas da família, aluguéis, aplicações financeiras e patrimônio familiar, que é considerada, por eles, como a fonte de renda principal. Eles não dependem da renda oriunda da atividade de personal para se manterem, sendo considerada uma fonte secundária de renda. Marta, personal stylist recebe uma pensão do ex-marido. Dora, personal organizer recebe mensalmente dividendos da construtora de seu pai, na qual é sócia e seu marido é alto funcionário do judiciário federal. Amadeu, personal dog walker recebe um rendimento mensal de alugueis de imóveis da família. Eduardo, personal trainer recebe dividendos da clínica da família, na qual é sócio e rendimento de aluguéis. Alexandre, personal xamã recebe dividendos da empresa da família, na qual é sócio, embora não atue na empresa.

- Frequentaram colégios particulares considerados os melhores na época e, na graduação, excelentes universidades particulares e/ou federais. Têm pósgraduação em entidades acadêmicas do mesmo nível e realizam periodicamente cursos no exterior para aprimoramento de seus conhecimentos. Além disso, cursaram parte do segundo grau nos EUA (Intercâmbio High School) e têm proficiência em mais de um idioma (Inglês e Espanhol ou Inglês e Francês). Igualmente realizam viagens anuais (uma a três) para participar, como alunos, em cursos (de duas a três semanas) relacionados às respectivas áreas de atuação, sem contar as viagens de lazer. Resumindo, são pessoas "viajadas", têm experiência internacional e conhecem muitos países.

- Os personals considerados "bem-sucedidos" não divulgam seus serviços através de sites, blogs ou redes sociais; esta se dá por indicação (boca a boca), sendo que o único material de que dispõem é o cartão de visita. Os personals "bemsucedidos" amealham clientes por intermédio das relações pessoais. 
- Veem-se como pioneiros e empreendedores e orgulham-se disso, o que se deve ao fato de terem sido os primeiros a entrar no ramo personal na área em que atuam. Orientam e justificam a sua atuação através do discurso do empreendedor significando pioneirismo, audácia, empoderamento, característica de quem sabe enxergar oportunidades de mercado e transforma-as em um negócio. Segundo seus comentários:

Comecei a ser personal trainer numa época (meados dos anos 1990) em que quase ninguém sabia o que era isso, eu fui um dos pioneiros, um verdadeiro empreendedor que soube enxergar a oportunidade. (Eduardo, personal trainer).

Quando comecei a trabalhar como personal stylist, em 2002, a profissão era tão desconhecida e inovadora que as pessoas que eu atendia nem sabiam pronunciar direito e muito menos tinham noção que existia esse tipo de profissão; eu sou uma das primeiras a atuar no ramo aqui em Porto Alegre, sempre tive espírito empreendedor, desde adolescente quando fazia, por brincadeira e distração, batinhas de batik para minhas amigas (Marta, personal stylist).

Acharam que eu estava enlouquecendo quando decidi que era hora de deixar a Arquitetura de uma vez e assumir de vez minha condição de personal organizer, mal sabiam que eu tinha vislumbrado uma super brecha no mercado cheinha de oportunidades. Aliás, os empreendedores sofrem essa discriminação (Dora, personal organizer).

Não nego que fui pioneiro no ramo, mas tornar-me personal xamã foi consequência da minha caminhada espiritual [...] esses dias me chamaram de empreendedor do espiritual [...] risos [...] é bem isso, ousei (Alexandre, personal xamã).

- Ingressaram ou optaram pela atividade de personals após alguma ruptura na sua trajetória de vida: morte do cônjuge e do filho, separação, falência da empresa, problemas de cunho jurídico e de saúde, ruptura de sociedade de forma desfavorável e opção por uma profissão que fugisse da tradição familiar.

Os personals "bem-sucedidos" se concebem como self-made-man ou self-madewoman, aqueles que se fazem por si mesmo, ou seja, pelo seu talento e competência em vislumbrar oportunidades, que se faz por meio de suas realizações, da sua vontade, independentemente da origem, ligações familiares e relações pessoais. Nesse contexto, eles consideram-se pessoas singulares e independentes das relações de parentesco e rede de contatos. Contudo, a ascendência, as conexões familiares e a rede de relações pessoais foram cruciais para o êxito de suas trajetórias e configuração em "personals 
bem-sucedidos". Eles dispõem de todos os tipos de capitais - econômico, social, cultural e simbólico -, o que lhes permite transformá-los em trunfos e reconvertê-los cada vez mais em capital econômico (Bourdieu, 2000; 2005). No relato das suas trajetórias evidencia-se a exaltação do indivíduo como valor, logo, o indivíduo autônomo (Dumont, 1993), que devido a suas características sui generis consegue alcançar o sucesso profissional e ser reconhecido por isso. Nos termos de Gilberto Velho (1994 e 2004), seus percursos têm uma dimensão mais racional e consciente, a de "projeto individual" (Velho, 1994 e 2004), que se verifica por meio dos planejamentos de carreira e de vida que eles elaboram para si. A outra é dada pelo contexto familiar, recursos econômicos e relações pessoais, ou seja, o "campo de possibilidades" (Velho 1994 e 2004). Ambos propiciaram a metamorfose (Velho, 1994) dos informantes em "personals bem-sucedidos".

Refletindo sobre os cinco informantes "bem-sucedidos" - Marta (personal stylist), Eduardo (personal trainer), Dora (personal organizer) e Alexandre (personal xamã) e Amadeu (personal dogwalker) percebi que eles se tornaram personals em razão do que Bourdieu (2000:359) chama de trajetória interrompida. Por exemplo, passaram por uma experiência dolorosa em suas trajetórias de vida, tais como: morte do cônjuge, separação, doença ${ }^{18}$, constrangimentos em relação à justiça, revanches políticas, ruptura com a tradição de seguir a profissão da família como médico ou como empresário, ou seja, vivenciaram a experiência de uma trajetória interrompida (Bourdieu, 2000:359). Consequentemente, a passagem para a área de consultorias pessoais pode ser interpretada como um refugio honroso (Bourdieu, 2000,p.363), ou seja, significando uma estratégia para manter-se na posição dominante ocupada pela familia.

Os "bem-sucedidos", também podem ser identificados como o que Guy Standing (2015:24) nomeou de "proficians", termo que deriva da combinação das palavras "professional" e "technician" e conforme a sua definição: detém um conjunto de habilidades que podem ser vendidas, recebendo altos rendimentos, como consultores ou trabalhadores autônomos.[...] A "relação de emprego padrão" não serve para eles. De acordo com Standing (2015) os "proficians" são peritos em uma determinada área de trabalho, alcançando altos rendimentos. Assim como os personals, são especialistas em diversas áreas como: organização, condicionamento físico, estilo, etc. e, como aponta

18 Doenças em que alguns informantes ficaram impossibilitados por períodos relativamente longos de exercer atividades profissionais. 
Standing (2105), sua principal qualidade é que são orientados a projetos. Boltanski e Chiapello (2009) denominam esse tipo de trabalhador especializado e autônomo como habitante da cidade dos projetos. Segundo estes autores, os princípios que regem essa cidade, em que habitam os especialistas, são a extensão da rede de relações pessoais e a capacidade de fazer o maior número de conexões para ter oportunidade de contratar muitos projetos. Assim, como os personals "bem-sucedidos", dedicam boa parte do seu tempo ao adensamento da sua rede pessoal, o que assegurará uma demanda ininterrupta de serviços.

\section{"Aspirantes"}

Os "aspirantes" integram a segunda órbita, que gira em torno dos "bemsucedidos" e é constituída por um conjunto numeroso e diversificado de indivíduos. Os "aspirantes" constituíram a maior parte dos informantes desta pesquisa. A partir da pesquisa de campo, elenquei as seguintes características para definir essa categoria:

- São oriundos de famílias de estratos médios, são filhos de empresários de pequenas empresas comerciais e de serviço, funcionários de bancos públicos e privados e pequenos proprietários rurais, pessoas que não quiseram seguir ou não foram incentivados a seguir os negócios da família.

- Eles têm uma rede de contatos pessoal considerável e é composta por gerentes de recursos humanos de médias empresas, assessores de imprensa freelance e headhunters ${ }^{19}$ e que, de certa maneira, ajuda a impulsionar as suas carreiras de personals. Contudo, também, existem “aspirantes" cuja rede é circunscrita a familiares, vizinhos, colegas e ex-colegas de trabalho.

- Sua renda depende de Planos de Demissão Voluntária - PDVs, FGTS, poupança, pequenas aplicações financeiras e venda de bens, por exemplo, automóveis e motocicletas. Segue o depoimento de um interlocutor desta órbita:

[...] quando recebi o meu PDV, nooossa parecia que tinha ganho na Mega Sena! Mas o dinheiro se foi em terapia, empresa de recolocação, pagando um designer gráfico para fazer meu logo, site e folder, impressões do folder e cartão, brindes para distribuir aos futuros clientes, nos eventos da área em São Paulo e no Rio, em assessoria de imprensa, em roupas de boa qualidade, em passaportes para o Fronteiras do Pensamento, almoços no Tá na mesa (almoços na Federasul) e no

${ }^{19}$ Headhunter: profissional tem uma vasta rede de contatos nas empresas que atua na recolocação de executivos. 
restaurante internacional da FIERGS e assim o din-din se foi [...] é muito trabalho fazendo contato para pouco fechamento[...] o mercado gaúcho é avesso às novidades[...]e ainda tem mais essa para dar aula em pós-graduação preciso ter mestrado, pode? A minha experiência não vale nada sem um mestrado. Se não fossem essas consultorias do SEBRAE, tava ralado. (Almir contador e administrador de empresas, aspirante a ser Personal Invest, "bem-sucedido").

- Estudaram em colégios públicos considerados médios e cursaram universidades privadas que não eram, na época, consideradas top de linha ou de renome. Não falam línguas estrangeiras e não viajam ao exterior para se capacitar; alguns viajaram a lazer para Buenos Aires e para as cidades fronteiriças com o Uruguai para comprar nos freeshops.

- A órbita dos "aspirantes" é composta por indivíduos que começaram as atividades de personal no final dos anos 90 e início dos anos 2000. O motivo para atuarem como personals encontra pontos em comum: incapacidade de dar sequência na carreira de executivo, ou dificuldade para serem aprovados em algum concurso público, ou para assumir a condição de empresário, ou ainda há os que trabalhavam em atividades de grande responsabilidade e eram mal remunerados ${ }^{20}$. Alguns atuavam em cargos executivos de média e alta gerência $^{21}$, no setor privado, e foram demitidos.

Os que trabalhavam no setor público em funções semelhantes, aderiram aos Planos de Demissão Voluntária (PDVs), motivados por abrir o próprio negócio ou adquirir uma franquia, investir o PDV no pequeno negócio da família, estudar para concurso público, tornarem-se mães e ficar cuidando do filho até a idade de ir para escola. Outros informantes tiveram que se demitir dos empregos, devido à transferência do cônjuge (esposas, em maior número) para acompanhá-los. Também havia informantes mulheres que pararam de trabalhar, pediram demissão para poderem cuidar dos filhos e, agora que estes estão na universidade, tentam voltar a trabalhar, mas não

\footnotetext{
${ }^{20}$ Exemplo: Designers gráficos que se tornam Personals Stylist; Arquitetas, Advogadas, Engenheiras de Produção, Secretárias Executivas que se tornam personal organizers e/ou personal assistent, Contadores/Administradores aposentados que se tornam personals planer ou personals invest.

${ }^{21}$ Conforme os informantes, o executivo de média gerência é responsável pela dotação orçamentária do seu setor e também por colocar em prática, através da sua equipe, os objetivos operacionais da empresa, recebendo pressão de todos, a saber, das diretorias, das equipes, dos clientes, dos outros gerentes, dos departamentos e dos fornecedores. Atua em atividades específicas, que exigem profundo conhecimento e toma decisões endossadas pela gerência sênior ou alta gerência. Já o executivo de alta gerência ou sênior é responsável por mais de um setor e, além de ser responsável pelo orçamento dos setores subordinados a ele, também participa junto com a diretoria das decisões estratégicas da empresa. Ainda, tem autonomia para tomar decisões e agir fundamentado no conhecimento e experiências adquiridos ao longo da carreira e nas informações que são fornecidas pela média gerência. Ambas as gerências podem gerenciar projetos.
} 
conseguiram se recolocar. E houve outros informantes que estavam sem recolocação há algum tempo e tentaram sem sucesso a carreira acadêmica.

- Alguns "aspirantes" iniciaram na atividade personal pela orientação de headhunters, que os aconselharam, como parte do percurso de recolocação no mercado de trabalho, a desenvolverem seu lado empreendedor, ou seja, a iniciarem sua preparação para atuarem na área de consultoria. Dessa maneira, eram orientados a frequentar cursos de empreendedorismo da Escola de Administração da Ufrgs e o Workshop Empretec ${ }^{22}$. Outros foram aconselhados e encorajados por seus terapeutas a seguir em "carreira solo", ou seja, resignificar a dispensa da empresa, fazendo dela uma oportunidade para, conforme o comentário de um informante, "desabrochar meu lado empreendedor que ficara escondido por anos de trabalho com carteira assinada". Outros foram estimulados por amigos e familiares a empreenderem e a procurarem o SEBRAE $^{23}$ diretamente. No aconselhamento e na recomendação de headhunters, de terapeutas e de familiares, fica evidente a grande influência da ideologia do empreendedor, difundida pelo Sebrae desde o início da década de 1990 (Leite e Melo, 2008; Melo, 2008). Os "aspirantes" apresentam depoimentos muito similares sobre o empreendedorismo, como os que seguem:

Vivemos num mundo sem emprego, mas com trabalho, então, ser empreendedor é a única saída (Pedro formado em Educação Física, aspirante a ser personal trainer bem-sucedido).

Aprendi nos cursos do Sebrae que não existe crise e sim oportunidades e que a palavra crise em japonês contém em si a oportunidade. Nem na história do agricultor da aldeia chinesa, nem tudo é ruim, nem tudo é bom, tudo depende [...] essa historinha parece boba, mas não é [...] ela me guia, sempre que estou ficando pra baixo me lembro dela, uma mensagem muito bonita ${ }^{24}[\ldots]$ agora entendo que a minha

${ }^{22}$ O Empretec é um seminário (com metodologia elaborada pela Organização das Nações Unidas -ONU) voltado para o desenvolvimento de características do comportamento empreendedor e para a identificação de novas oportunidades de negócios, promovido em 34 países. Aqui no Brasil o seminário Empretec é difundido pelo Sebrae(www.sebrae.com.br).

${ }^{23}$ Geralmente os aspirantes que detém maior poder aquisitivo participam do Workshop Empretec, que é o mais caro, custando em torno de R \$1.000,00. Por outro lado, os que têm menos recursos financeiros participam de outros cursos, tais como: AE: Aprender a Empreender, IPGN: Iniciando um pequeno grande negócio, que são cursos online oferecidos gratuitamente pelo Portal Educação do Sebrae ( www.ead.sebrae.com.br) e outros presenciais, também, oferecidos pelo Sebrae, como: Oficina de Plano de Negócio, Oficina de Empreendedorismo, Palestras sobre empreendedorismo, Formação de preço, que foram os mais citados pelos informantes.

${ }^{24}$ Nesse instante, pediu-se a ela que contasse a história do Mestre Zen, e ela mostrou o quadrinho pendurado na parede no qual a história estava escrita: Um agricultor que tinha trabalhado durante muitos anos na terra tinha um cavalo do qual gostava muito. Um dia, o cavalo fugiu, e os vizinhos, por 
demissão não foi ruim, e sim foi uma oportunidade para desenvolver as minhas características empreendedoras adormecidas (Eugênia, aspirante a ser personal organizer bem-sucedida).

- Alguns aspirantes divulgam seus serviços por meio de sites e blogs, prospectos (folders), redes sociais e cartão de vistas, além disso, oferecem cursos nos sites e blogs e participam de eventos empresariais e festivos ${ }^{25}$, o que, de acordo com seus relatos, confere a eles visibilidade e prestígio, além de conhecerem pessoas de diferentes áreas e potenciais clientes. Conforme os "aspirantes", a formação de uma clientela pode demorar muitos anos (de 10 a 20 anos) ${ }^{26}$; "é um trabalho de formiguinha, contínuo, devagar e longo".

No conjunto dos personals que se entendem como "aspirantes", pude perceber que eles foram arrebatados por um conjunto de discursos correntes nos meios de comunicação que estão fortemente centrados na liberdade, autonomia e realização. Por um lado, existe o discurso dos personals de sucesso, que têm programas na TV e que, em entrevistas, enfatizam ${ }^{27}$ dois aspectos como pontos fortes do ofício, a saber, que a área de serviços pessoais é um celeiro de oportunidades e permite "grande liberdade de $a c ̧ a \tilde{o}{ }^{28, " ~(s i g n i f i c a n d o ~ n a ̃ o ~ e s t a r ~ s u b o r d i n a d o ~ a ~ a l g u e ́ m, ~ a l e ́ m ~ d e ~ t e r ~ t o t a l ~ c o n t r o l e ~ s o b r e ~}$ as suas decisões e práticas profissionais). Dito de outro modo é o discurso do indivíduo realizador centrado na ideologia ${ }^{29}$ do empreendedor, que é fortemente disseminado pelo Sebrae e pelos meios de comunicação. Por outro lado, o que conta é o baixo

solidariedade, foram junto dele e disseram-lhe por simpatia: "Que azar!". Perante esta manifestação de pesar, o agricultor limitou-se apenas a tecer o seguinte comentário: "Talvez!..." Quinze dias depois, o cavalo regressou e trouxe com ele uma tropa de cavalos selvagens e, os vizinhos vieram, desta vez, congratular-se com a boa sorte do agricultor. Ele disse, apenas: "Talvez!..." No dia a seguinte, o filho do agricultor tentou montar um dos cavalos selvagens, caiu e quebrou uma perna. De novo, os vizinhos voltaram e lamentaram a pouca sorte do agricultor. E ele respondeu: "Talvez!..." Duas semanas se passaram e um grupo de oficiais do imperador veio à aldeia para recrutar os jovens para o exército real mas, devido à perna ferida, o filho do agricultor não foi escolhido. Quando os vizinhos vieram dar os parabéns ao velho agricultor, congratulando-se com as voltas da sorte, ele apenas disse: "Talvez!..."

${ }^{25}$ Como a inauguração de restaurantes, lojas, vernissages, exposições, eventos artísticos, entre outros.

${ }^{26}$ Ao verificar com alguns aspirantes como eles sabiam que levaria de 10 a 20 anos para formarem uma clientela estável e rentável, eles responderam que obtiveram a informação ou através das empresas de recolocação ou pelos cursos sobre empreendedorismo, marketing e plano de negócios dos quais participaram.

${ }^{27}$ Verificado em entrevistas realizadas com os personals "bem-sucedidos" e em alguns programas de TV tanto de variedades como programas de cunho mais empresarial como o Conta corrente (Globonews) ou Grandes Empresas Pequenos Negócios (Globo) e em eventos relacionados com a área em que personals reconhecidos como bem-sucedidos são entrevistados.

${ }^{28}$ A expressão é citada por vários "personals aspirantes", pois ela faz parte do repertório de expressões de efeito que os palestrantes utilizam ao proferirem as suas palestras.

${ }^{29}$ Entendida no sentido dumoniano significando o conjunto social de representações; conjunto das ideias e valores comuns numa sociedade = ideologia global (Dumont, 1993:279). 
investimento inicial necessário para entrar no mercado de consultorias pessoais, considerado por eles como mais barato do que abrir uma empresa física (loja, restaurante, tele-entrega ou adquirir uma franquia). Percebi que os "aspirantes" não se deram conta de que os "bem-sucedidos" têm dois recursos valiosos, a saber: a ampla e diversa rede de contatos pessoais, que garante a divulgação e o fluxo de clientes; e não dependerem da renda oriunda da atividade personal para viver. Assim, são dois recursos que lhes conferem a estrutura necessária para poderem atuar no ofício (Sennett, 2006). Deste modo, os "aspirantes", influenciados pelo discurso do empreendedor, pelos relatos de sucesso dos "bem-sucedidos" e sem investigar este tipo de trabalho mais detalhadamente, utilizaram as suas economias ${ }^{30}$ para iniciar as atividades como prestadores de serviços pessoais, como mostra o relato a seguir:

[...] aprendi que empreendedor de verdade se sacrifica hoje para ganhar amanhã, já dizia o meu avô quem arrisca não petisca, tem que subir na árvore para pegar a maçã e se a gente cai, a gente insiste e sobe de novo, aprende a subir sem cair e pega a maçã. Cair da árvore faz parte! No curso do Sebrae o instrutor falou sobre um monte de empreendedores que venderam tudo o que tinham, desapego total, para montar o negócio dos seus sonhos [...]porque tinham fé, acreditavam na intuição que tinham enxergado oportunidades. Eu quero muito ser personal organizer, tenho talento natural para isso, sabe, seguir a carreira personal. Tô cansada[...] trabalhei como técnica de qualidade e de segurança e fazia parte da equipe que organizava eventos e promoções na empresa[...] já tá mais que na hora de seguir a minha vocação, nasci pra isso[...]comecei a fazer os cursos do SEBRAE porque tava todo mundo falando e são baratos e tava cheia da empresa[...]promoção só pros outros, nunca chegava pra $\operatorname{mim}[\ldots .$.$] sempre faltava alguma coisa[...]briguei com o chefe e fui pra rua. A grana da$ indenização foi boa, mas foi embora ligeirinho [...]fiz cartão de visita, marca e blog com a ajuda do SEBRAE, depois fiz curso de organização a distância pela $\mathrm{OZ}$ Cursos e fui a Sampa participar do congresso de organização da OZ. Tô fazendo cursos, divulgando entre as amigas, parentes e no bairro[...] até agora não apareceu[...]tô fazendo uns bicos como promotora de vendas e ajudando com os eventos da empresa que trabalhava, não é o que eu quero, mas faz parte , né?(Eugênia graduada em Tecnologia de gestão da qualidade pela Uniasselvi, "aspirante" a personal organizer "bem-sucedida").

Como relata Eugênia, no começo da "carreira personal" o montante de capital vindo do FGTS lhe conferiu alguma estrutura e garantia, mas "foi embora ligeirinho". Quando suas reservas financeiras chegaram ao fim, devido ao intenso investimento em divulgação e em cursos de capacitação em personal organizer, a solução é a volta aos trabalhos temporários e precários. Apesar das dificuldades enfrentadas, os que partilham as mesmas expectativas persistem na tentativa de exercerem a atividade de personal, participando de cursos para aprimorar as suas qualidades empreendedoras, bem como de

\footnotetext{
${ }^{30}$ Poupança, PDVs, FGTS e recursos oriundos da venda do carro.
} 
treinamentos na área de atuação e tentando angariar clientes através das redes sociais para no futuro serem "personals bem-sucedidos".

Os “aspirantes" assemelham-se com o que Guy Standing (2015:28) denomina de precariado, ou seja, indivíduos desprovidos das sete formas de garantia relacionadas ao trabalho, que, conforme o autor, são: garantias de mercado de trabalho, vínculo empregatício, reprodução de habilidade (oportunidades de aquisição de habilidades) e de representação e segurança no emprego (manter o emprego e oportunidades de promoção), no trabalho (proteção contra acidentes, doenças, compensações) e de renda.

Os “aspirantes” atuam em trabalhos frágeis, precários, instáveis, informais, temporários, em regime parcial, possuem a ilusão de que, trabalhando por conta própria, atingiriam maior realização profissional; além disso, estando sujeitos a rendimentos baixos e variáveis, encontram-se expostos à incerteza crônica (Standing, 2015:195).

\begin{abstract}
Quando decidi ser personal assistent, estava bem empolgada, ainda mais depois que fiz o Empretec, achava que meu negócio ia alavancar rápido, afinal, hoje em dia ninguém tem tempo para levar e buscar roupa na lavanderia e sapato em sapateiro, esperar o "cara da NET", aturar encanador, ir no São Pedro ou Bourbon comprar ingressos ou comprar via internet e muito menos perder tempo procurando qual a loja que vende o refrigerador mais barato, né?[...] Achei que a oferta do PDV era a grande chance da minha vida, um aviso dos céus...que nada. As vezes sinto saudades da carteira assinada, mas quando penso no minha ex-chefa e na pressão que a empresa fazia, dou graças a Deus por ter saído. Carteira assinada não é segurança, eles te botam na rua a qualquer hora, sendo competente ou não. Tudo se resume a reduzir custos. O bom é que tenho bom nome e conhecidos na área e que me chamam para fazer serviços para eles [...] depois de cinco anos na área ainda existem períodos que o serviço fica escasso. [...] antes tinha uma vida mais calma e planejada, mas o ambiente de trabalho ruim. Hoje não tenho nem cartão de crédito, não dá, pago tudo à vista e no débito [...] hoje tem a nova classe média e eu sou a nova classe pobre (gargalhadas), só rindo para não chorar. Mas tenho um mantra que me sustenta nessas épocas difíceis: Eu sempre volta à luta, sou resiliente, permaneço de pé. Sou forte e firme. As dificuldades fazem parte do meu caminho de empreendedora. (Zuleica, graduada em Relações públicas, trabalha como promotora de eventos, "aspirante" a personal assistent "bem-sucedida").
\end{abstract}

Os "aspirantes", também necessitam investir tempo em outras tarefas: criar seu currículo, mantendo-o atualizado; desenvolver e manter sua rede de contatos pessoais, vendendo seus serviços ou oferecendo algum trabalho temporário e participar de cursos de atualização e eventos de atualização, em sua área ou em áreas afins. Assim demonstram os relatos dos “aspirantes" Pedro e Eugênia:

Às vezes fica pesado levar adiante meu sonho de ser um personal "bem-sucedido", tipo viver só disso. Eu sou só um e tenho que prestar o serviço, me vender, ir de uma academia a outra para atender às vezes um ou dois alunos, dá um cansaço, mas sigo em frente, brasileiro nunca desiste. Tem que fazer do limão uma limonada! (Pedro graduado em Educação física, "aspirante" a ser personal trainer "bem-sucedido".). 
Quando tive a ideia de ser personal organizer, nunca pensei que dava tanto trabalho, mas como meu pai diz, nada se consegue sem esforço, por isso eu continuo. Hoje tive que fazer um resumo do meu currículo, dar uma ajeitada porque uma empresa que eu mandei uma proposta de palestra queria saber minha formação, minha história, antes de fechar comigo [...] a gente perde um tempão fazendo isso [...] outra coisa que perco tempo é visitando conhecidos e deixando brindes, as canetinhas e caderninhos, afinal tenho que me vender, o serviço não aparece do nada, tenho que me divulgar. Como aprendi no Empretec contratempos e fracassos não são o oposto do sucesso são parte do rumo ao sucesso! (Eugênia, "aspirante" a ser personal organizer "bem-sucedida").

Finalmente, os "aspirantes" aceitam trabalhar em empregos temporários. Eles acreditam que dessa forma podem adquirir várias experiências, o que favorecerá seu projeto de transformarem-se em personals "bem-sucedidos" e, também, por questões econômicas, já que necessitam de uma remuneração para se manterem, até conseguir manter-se somente por meio da atividade personal.

Enquanto ainda não consigo sobreviver só do trabalho de personal stylist, eu faço alguns serviços para a empresa que eu trabalhava. Organizo algumas promoções de venda em feiras e eventos e até em supermercados. Não queria mais trabalhar nisso, me incomoda, mas fazer o que, né? Tenho que me sustentar de um jeito ou de outro. Tudo pela causa, tenho uma meta maior[...] aí engulo a incomodação, ela fica pequena, faz parte né? Nos cursos de empreendedorismo aprendi que essa trabalheira faz parte da trilha do empreendedor, traz experiência e aprendizado para alcançar o sucesso. $\mathrm{O}$ bom é que não tenho que dar RPA ${ }^{31}$, tudo por fora, embolso toda a grana, eles sabem que podem confiar em mim. (Andrielly, Tecnóloga em Design de Moda/Senac, trabalha como promotora de vendas, "aspirante" a ser personal stylist "bem-sucedida").

Achei que, com a crise, o serviço de promoção ia diminuir, que nada, aumentou, tenho trabalho quase todos os dias e até finais de semana, tudo por RPA, grana boa, meu Natal vai ser bem bom, pelo menos isso. E eu acho que, em janeiro, vou conseguir uns bicos de promoção na praia. Não gosto muito de fazer isso, mas vale a pena pela grana e aproveito para divulgar meu trabalho de personal organizer, sempre tem alguém que precisa organizar coisas na casa da praia. Eles vão me ajudar a divulgar meus serviços de personal organizer, já fiz uma arrumação de guarda-roupa para a mãe do meu ex-chefe, ele sabe que pode confiar em mim. Tudo tem seu lado bom, contratempos e a sensação de fracasso mostram que eu estou tentando seguir meus sonhos. Do limão faço uma bela torta de limão. (Eugênia, "aspirante" a ser personal organizer "bem-sucedida").

Em outras palavras, os "aspirantes" pertencem à "economia das sombras" (Standing, 2015: 93), ou seja, a economia informal composta por trabalhadores sem registro, dessa maneira invisíveis ao estado, sem proteções e sem pagar impostos. Em suma, pode-se dizer que alguns "personals aspirantes" fazem parte do que o autor (2015) define como

\footnotetext{
${ }^{31}$ RPA: Recibo de Pagamento Autônomo: recibo que o prestador de serviço deve preencher após a realização deste. Para emitir uma RPA a pessoa deve estar registrada como autônoma na prefeitura do município onde mora. A RPA abrange as taxas de IRRF (Imposto de Renda Retido na Fonte), INSS (Imposto Nacional de Seguridade Social) e ISSQN (Imposto Sobre Serviço de Qualquer Natureza).

Fonte: http://www2.portoalegre.rs.gov.br/smf/default.php?reg=11\&p_secao=114.Acessado em 10/12/2016.
}

Iluminuras, Porto Alegre, v. 21, n. 52, p. 119-158, abril, 2020. 
precariado progressista, que é o resultado de políticas de terceirização, da automação das áreas administrativas, da implementação de tecnologias gerenciais como reengenharia e downsizing e da eficácia da ideologia do discurso empreendedor. Assim, "os aspirantes" que são profissionais graduados e alguns com especialização ficaram à deriva no mercado, com uma situação profissional incerta (Antunes, 2009;2011; 2019).

Madalena, personal friend, também se encaixa nos "aspirantes", ela almeja no futuro adquirir a maior parte de sua renda atuando como personal friend, ser uma "personal friend "bem-sucedida". Madalena conta que ainda precisa trabalhar meioturno para poder garantir a aposentadoria, pagar as contas e viver. Ela considera que a renda obtida como personal friend é um extra ou nos seus termos o meu pé de meia, estou investindo numa profissão para quando me aposentar. Deus me livre ficar em casa fazendo crochê, e reclamando da vida. Sou empreendedora, vou a luta, quem sabe faz a hora não espera acontecer! No entendimento dos "aspirantes" ser "bem sucedido" significa conseguir manter-se somente com trabalho de personal.

\section{“Aventureiros ou Oportunistas"}

Os indivíduos pertencentes à órbita periférica são jovens nascidos a partir da década de oitenta, graduados e oriundos de camadas sociais menos favorecidas. No entanto, enxergam na atividade personal um meio para ingressar no mercado de trabalho e conferir a sua atividade certa sofisticação, como demonstram os relatos a seguir:

Me formei em Moda e, como trabalho tá difícil, resolvi empreender, fiz um blog com dicas de moda de rua e dos desfiles internacionais, misturando os dois, com meu tempero. Também ofereço serviço de personal stylist, ofereço serviços de modelista e, vou empreendendo até achar um emprego de estilista na Renner, Zara, C\&A, Riachuelo. Pelo menos nas entrevistas não digo que estou desempregada, digo que sou empreendedora, que já trabalho na área de estilo, que tenho um blog, é chique ser personal stylist, vou me virando. Também fiz curso de empreendedorismo no Sebrae. Porque vamos combinar se formar em Moda para trabalhar de vendedora de loja não dá, né? (Janice, 21 anos, formada em Tecnólogo em Design de Moda/Senac).

Comecei assistindo esses programas de arrumar a casa tipo "Santa Ajuda" e "Cada coisa no seu lugar" e achei que poderia ser uma boa investir nisso. Tá tudo no Youtube. Enquanto estudo para concurso, já que na minha área não aparece nada de bom, minissalário, maxi-trabalho. Li bastante coisa na internet sobre organização. Pelo menos não fico parada, né? Empreendendo na área de personal organizer. Se até arquitetas e artistas trabalham nisso [...] refinadíssimas [...] me ajeito até passar num concurso (Kátia, 26 anos, formada em Pedagogia). 
Os "aventureiros" enxergam o oficio de personal como um degrau ou uma passagem para um trabalho ou função que consideram mais atrativa e bem remunerada, como: funcionário público ou como empregado de grandes empresas com carteira assinada. Eles, ao considerarem a atividade de personal como uma forma temporária de trabalho, não são bem-vistos pelos "aspirantes" e pelos "bem-sucedidos", como exemplificado através dos comentários abaixo:

[...] inflacionam o mercado, não sabem nada, esses aventureiros (Almir, "aspirante" a personal invest "bem-sucedido").

[...] deixam os possíveis clientes perdidos com tanta oferta, não passam de uns oportunistas, amadores não têm noção do que é trabalhar com educação física e nem com pessoas ("Pedro, "aspirante" a personal trainer" bem-sucedido").

[...] queimam o filme da profissão, sem experiência, não passam de uns aventureiros (Eugênia, "aspirante" a personal organizer "bem-sucedida").

[...] essas nuvens passageiras são uns irresponsáveis, aventureiros e oportunistas (Eduardo, personal trainer "bem-sucedido").

Nos comentários acima nota-se um sentimento de indignação dos "aspirantes" e dos "bem-sucedidos" em relação aos "aventureiros". Esse sentimento negativo expressado pelos "aspirantes e "bem-sucedidos" é gerado pela percepção que estes têm da falta de experiência no exercício da atividade personal por parte dos "aventureiros" e, também, porque estes últimos assumem abertamente que estão na atividade personal de forma transitória. Os oportunistas assim como o malandro (DaMatta, 1997) vivem nas brechas da sociedade, das suas incoerências, dos seus paradoxos, criando seu próprio espaço de ser e estar no mundo e sobreviver das suas aptidões pessoais.

Para os "aventureiros/oportunistas" trabalhar de forma temporária e informal é mais uma estratégia para conhecer pessoas que poderão, futuramente, propiciar-lhes contatos com pessoas importantes e, com isso, conseguir-lhes uma melhor colocação profissional. O termo personal também é importante, pois dá prestigio à profissão.

[...] imagina se eu disser que sou autônomo, nada a ver, vão pensar que sou despachante, ainda existe isso? Meu tio, que Deus o tenha, era despachante [risos] um Zé ninguém[...]desde o início a gente tem que ser chique[...].meu pai sempre me disse não te mixa, bota banca, o que vale é mostrar para os outros que tu tá por cima da carne seca.....P E R S O N A L.... [pronunciando a palavra solenemente].Todo mundo sabe que gente chique tem personal. (Felipe, 25 anos, formado há 18 meses em Educação Física, exemplo de "aventureiro"). 
Usar o nome da atividade em inglês é uma estratégia que confere status à profissão e seus profissionais; e pode dar a entender que sua clientela é de nível social e cultural elevado e alto poder aquisitivo.

\section{Personal: uma categoria de distinção no mercado de serviços}

Ao longo do artigo procurei mapear como surgiu a profissão de personal. Dito de outro modo averiguou-se, por meio de reportagens de revistas, quem é chamado de personal e através da internet quem se anuncia e se autodenomina de personal e por último, pesquisando o segmento que se autodenomina personal pode-se depreender como eles se pensam. A pesquisa na mídia mostrou quando esse termo começou a ser utilizado, a imiscuir-se no imaginário da população e a nomear serviços exclusivos, sofisticados e sob medida e que um serviço com estas características era apanágio de estratos economicamente favorecidos, ou seja, serviços que continham no seu cerne distinção.

Conforme verificado o primeiro serviço denominado de personal a despontar foi o de personal trainer, ou seja, foi a partir dele que se estabeleceu um núcleo, uma novidade que passou a ser sinônimo personal. Com base no modelo do personal trainer começou a ser usada a ideia (noção) desse serviço, que começou a ser denominado pela população de especializado e personalizado. Assim surgiram outros serviços nessa configuração a ponto disso tornar-se um modelo para outros tipos de personals, brotando uma miríade destes, o que aponta para a difusão e potência que esse modelo adquiriu no imaginário da população brasileira.

Alguns dos serviços personals pesquisados denominam ocupações já existentes que somente mudaram de nome, ou seja, passaram a utilizar o anglicismo personal com o intuito de reinventá-las, de conferir-lhes sofisticação e de remeter a serviços prestados sob medida (taylor made), ou seja, exclusivos. Assim, indicando uma tentativa de dar destaque a certos serviços, isto é, buscando propiciar um diferencial no mercado em que tais serviços são consumidos. Como é o caso de alguns destes profissionais que oferecem seus serviços na internet como, por exemplo, os personals nerd e os personals play.

Personals Nerd que são técnicos em informática que realizam serviços a domicílio tais como ensinar a configurar smartphones, televisões, computadores, 
videogames, redes, impressoras e demais dispositivos eletroeletrônicos. O personal play que é outro nome utilizado por recreacionistas que além de atuarem em festas infantis também atuam a domicílio. Em relação aos informantes também se observou, que alguns, como os "aventureiros e oportunistas" utilizam a denominação personal para disfarçar a sua situação transitória de trabalho precário, o popular "bico", conferindo-lhe distinção. Outros informantes, por sua vez, atuam em profissões já existentes e passaram a autodenominar-se de personals, para conferir, principalmente, distinção e dar a entender que de certa maneira o serviço é feito sobmedida. Tânia se intitula personal decór, segundo ela

[...] nomes como Decorador de Interiores ou Designer de Interiores, já estavam muito batidos [...] o trabalho do decorador é sempre pessoal, não tem como não ser desse jeito, impossível, eu não posso impor meu gosto e também não vou empurrar para meus clientes a tendência só porque tá na moda, embora eu saiba de colegas que fazem isso, infelizmente, têm, né? Sempre fiz projetos de decoração ao gosto do freguês. Então para me diferenciar dos colegas que impõem o gosto deles pra cima dos clientes e daqueles que só decoram conforme a tendência e aí fica tudo igual, achei que usar a palavra personal seria muito bom, tive esse insight, uso para dizer exatamente isso "olha eu faço a decoração do teu jeito", os ambientes que eu decoro sempre ficam a cara do cliente e tá dando certo! Hoje em dia a concorrência é forte e a gente tem que ser criativa, sempre se inovar.

Ela optou por denominar-se de personal com a intenção de salientar que seus projetos são sempre individualizados respeitando as particularidades e gostos dos clientes e dar um diferencial mais requintado a sua atividade. Durante a pesquisa, percebi que as moradias por ela decoradas tinham estilos bem diferentes umas das outras, o que evidência que ela não impõe o seu estilo conforme comentou.

José se intitula personal husband e a sua família tem uma ferragem. Há uns dez anos ele, seu pai e o irmão começaram a notar que alguns clientes, principalmente, mulheres de várias idades e casais mais velhos, ambos morando sozinhos solicitavamlhes indicações de "gente de confiança" que fizesse reparos domésticos. Assim, como José sabia fazê-los decidiu oferecê-los para seus clientes.

O nome personal foi minha boa ideia, tem personal pra tudo, né? Só que personal conserta tudo, não dá. Então uma cliente, que é professora de inglês, me deu a dica usar a palavra marido em inglês. Os clientes já me conhecem aqui da ferragem e me indicam como "gente de confiança", sei fazer tudo quanto é reparo dentro de casa, faço um serviço limpo e caprichado, coisa que encanador e hidráulico ou eletricista não fazem [...] arrumam uma coisa e desarrumam outra, deixam a sujeira, não limpam. E tem mais, aumentou o faturamento da loja, porque se os clientes precisam de peças eu mesmo levo da ferragem. 
Ele escolheu se autodenominar assim (personal husband) para dar mais credibilidade e seriedade ao seu oficio de reparos residenciais, junto aos clientes, pois segundo o seu relato: "existe muita picaretagem e gente mal intencionada na área". Desde que começou a trabalhar como personal husband o faturamento da sessão de peças da ferragem aumentou, conforme visualizado na planilha da ferragem. Pude depreender que a sua atuação como personal husband também pode ser entendida como a de um vendedor externo, da ferragem da família, ou seja, como uma estratégia de venda.

A personal beauty, Ágata, tem formação de esteticista pelo Senac, comentou que a palavra personal

[...] é um nome mais chique, né? Ainda mais depois que passei a atender num espaço só meu. Imagina se eu botar na placa do prédio: Esteticista Ágata, sem glamour.[...] Eu trabalho com beleza, estudei, então tem que aparecer no nome, o nome tem que ter brilho.[...] Eu não sou que nem as colegas que trabalham em salão de beleza que atendem as clientes com barulho, música ambiente que as clientes não gostam, cheiro de produto de cabelo, cera derretida [...] tu sabe, né? Toda aquela "bufunfa" de salão.

Nota-se no seu relato que ela utiliza a palavra personal para conferir requinte a sua profissão. Ágata não atende a domicilio, ao contrário, ela atende em uma sala alugada com hora marcada. Os serviços prestados por ela são massagens de vários tipos e estética facial e corporal. Conforme Ágata, o serviço que ela realiza como personal beauty é o mesmo que ela realizava quando atendia em salões de beleza. No entanto, a sua sala está localizada em andar alto, tem ar condicionado, música ambiente, grandes janelas, ou seja, iluminada, bem decorada e silenciosa. Segundo Ágata, duas clientes que atuavam na área de Coaching a ajudaram: "a empreender e a voar sozinha na carreira de esteticista" e, também, lhe sugeriram que adotasse a denominação de personal beauty.

A teoria dos campos de Bourdieu $(2000 ; 2003)$ que entende a sociedade dividida em uma variedade de campos sociais (político, econômico, religioso, literário, intelectual, moda, esportivo, etc.) com graus diferentes de autonomia e que se formaram no decorrer da história é trazida aqui para analisar o uso da categoria personal. Sob o ponto de vista da presente pesquisa entende-se que existe um novo campo dentro do campo de serviços que é o campo personal. Os capitais (Bourdieu, 2000; 2003) valorizados são o aprendizado no convívio familiar, ou habitus (Bourdieu, 2000), tradição familiar, ter amplas e densas redes de contatos e não depender da atividade 
personal para viver. Dito em outras palavras, os capitais mais valorizados são: capital simbólico, econômico e o social (Bourdieu, 2000; 2003; 2005).

$\mathrm{Na}$ análise dos casos apresentados é visível que os profissionais estão querendo se posicionar melhor no campo (Bourdieu, 2000; 2003) dos serviços agregando a categoria personal como sendo uma forma de valorização da sua atuação. $\mathrm{O}$ terno personal pode ser interpretado como uma marca no campo dos serviços, ou seja, o termo se transformou em um elemento que tem valor, que é distintivo. Desta forma, colocando quem o utiliza num status mais elevado, no setor de serviços. Através dos relatos trazidos depreendi que categoria personal é uma categoria que faz sentido, que as pessoas reconhecem como tendo valor no mercado de serviços. Tanto assim que as pessoas se apropriaram dela de formas diferentes para agregar valor aos seus serviços. Assim, os profissionais se autodenominam de personal para se colocarem numa posição melhor no campo (Bourdieu, 2000; 2003) da prestação de serviços, porque essa categoria está instaurada nesse momento como uma categoria prestigiada.

Os profissionais - Dora, personal organizer; Marta, personal stylist, Eduardo, personal trainer, Madalena, personal friend e Amadeu, personal dogwalker -, além de utilizarem o termo para conferir distinção a sua atuação; também o utilizam significando seus serviços são "personalizados", ou seja, ajustam os serviços cada um a seu modo, cada um deles tem uma concepção diferente do que é "personalizar", isto é, cada um construiu a sua ideia do que é ser personal e prestar um serviço "personalizado". ${ }^{32}$

Em relação aos "aspirantes" eles estão longe de se conceberem como profissionais precarizados no mercado de trabalho, embora o vivenciem. Pelas suas falas percebe-se que se entendem como empreendedores em formação e que o insucesso, a incerteza profissional e a carência financeira, são temporários, ou seja, fazem parte do processo para vir a ser um empreendedor de sucesso. Para os “aspirantes" pesquisados conceber-se como profissional precarizado é colocar-se na posição de "vítima das circunstâncias", e, portanto, uma pessoa sem agência (Ortner, 2006), passiva a mercê da vida. Os "aspirantes" fazem suas escolhas orientados pelos preceitos ditados nos cursos de empreendedorismo (persistência, aumento sistemático

32 Este assunto é trabalhado em detalhes na tese Chama o personal: estudo etnográfico sobre consultorias pessoais (Dios, 2017). 
da rede de contatos, capacitação continuada, aprender com os fracassos, elaboração de metas e ter mobilidade) a prática destes faz com que eles resignificam o fracasso tratando-o como se ele fosse parte inerente do aprendizado para vir a ser um personal "bem-sucedido"; portanto, conseguir se manter por meio do trabalho de personal. O discurso do empreendedorismo é potente entre os "aspirantes" por que numa época em que se geram poucas oportunidades de trabalho com carteira assinada ele representa uma aparente saída de uma situação instável e precária. Como aponta Ricardo Antunes (2019) o empreendedorismo é um mito que ganha força em meio ao enfraquecimento das políticas sociais, ao alto desemprego e as novas tecnologias da informação.

\section{Palavras finais}

A oferta desses serviços deu-se num contexto de importantes transformações na sociedade brasileira que ocorreram desde o início da década de 1990. As pertinentes a esta pesquisa foram as políticas de terceirização, automação da área administrativa e a implementação de tecnologias gerenciais - como a reengenharia e o downsizing ( Donadone, 2001; Antunes, 2009, 2011, 2019; Standing, 2015). Outra mudança importante foi de ordem cultural, com a introdução da ideologia empreendedora (Leite e Melo, 2008 e Melo, 2008) que ganhou força de mito devido ao enfraquecimento das políticas sociais, ao alto desemprego e as novas tecnologias da informação (Antunes, 2019). Concomitante a essas mudanças, ocorreu uma ampla precarização do trabalho em diversos níveis salariais com (Antunes, 2009, 2011, 2019). No Brasil, o crescimento deste mercado de serviços pessoais e da profissão de personal aconteceu entre 2004 e $2014^{33}$.

Os personals formam uma categoria profissional fluida não existindo fronteiras precisas, nem critérios claros de pertencimento. Os personals se enxergam dispostos ao redor do que eles percebem como um bom exemplo de personal ou um personal "bemsucedido". Também havia aqueles que almejavam ser exitosos nessa profissão e que eram denominados pelos "bem-sucedidos" de "aspirantes". Por último, ainda, havia os que estavam na profissão de modo transitório e eram denominados pelos dois anteriores de "aventureiros ou oportunistas". Os personals que conseguem êxito na profissão são aqueles que detém todos os capitais ( Bourdieu, 2000; 2005). Além disso, o que pode se

\footnotetext{
${ }^{33}$ Dado obtido de forma empírica pela pesquisadora que monitora esse tipo de serviço desde 2008.
} 
perceber é que o papel social dos personals é de serem mediadores culturais (Bourdieu, 2000; Velho e Kuschnir, 2001) e que a denominação personal é uma categoria de distinção no mercado de serviços.

O discurso empreendedor é potente no meio dos "aspirantes", pois fornece uma explicação plausível para o fracasso e a incerteza na profissão de personal. Conforme argumenta tal discurso tanto o fracasso como a incerteza fazem parte da vida daqueles que optam por empreender. Ele consegue esse efeito por meio de exemplos descontextualizados de pessoas que empreenderam e tiveram êxito após alguns fracassos e trabalhos precários. Assim, dando a entender que o fracasso e a incerteza (que são ruins) fazem parte da vida trazendo coisas boas, ou seja, experiência e aprendizados que acarretam êxito no futuro.

\section{REFERÊNCIAS}

ANTUNES, Ricardo. As configurações do trabalho na sociedade capitalista. Revista Katálysis, v. 12, Jul/Dez 2009. ISSN 2. http://www.scielo.br/pdf/rk/v12n2/01

ANTUNES, Ricardo. Os modos de ser da informalidade:rumo a uma nova era da precarização estrutural do trabalho? Serviço Social \& Sociedade, São Paulo, p. 405-419, Jul/Set 2011. ISSN 107. http://dx.doi.org/10.1590/S0101-66282011000300002.

ANTUNES, Ricardo. Riqueza e miséria do trabalho no Brasil .volume IV. São Paulo: Boitempo, 2019.

BECKER, Howard S. Ousiders. Estudos de sociologia do desvio. Rio de Janeiro: Zahar (edição digital), 2014.

BOLTANSKI, Luc. Les Cadres.La formation d'un groupe social. Paris: Editions Minuit, 1982.

BOLTANSKI, Luc.; CHIAPELLO, Ève. O novo espírito do capitalismo. Tradução de Ivone C. Benedetti. São Paulo: WMF Martins Fontes, 2009. 
BOURDIEU, Pierre. La distinción. Critério y bases sociales del gusto. $2^{\circ}$ edição. ed.

Buenos Aires: Tauros, 2000.

BOURDIEU, Pierre. Questões de Sociologia. Lisboa: Fim de Século, 2003.

BOURDIEU, Pierre.; MICELI, Sérgio. A economia das trocas simbólicas. 6 edição. São Paulo: Perspectiva, 2005.

DAMATTA, Roberto. Carnavais, malandros e heróis. Para uma sociologia do dilema brasileiro. 6 ed. Rio de Janeiro. Rocco, 1997.

DIOS, Maria Luísa Célia E. Chama o personal: estudo etnográfico sobre consultorias pessoais. Tese de doutorado em Ciências Sociais, PUCRS, 2017.

DONADONE, Júlio. Os hunos já chegaram! Dinâmica organizacional, difusão de conceitos gerenciais e atuação das consultorias. São Paulo: USP, 2001.

DUMONT, Louis. O individualismo.Uma perspectiva antropológica da ideologia moderna. Tradução de Álvaro Cabral. Rio de Janeiro: Rocco, 1993.

GASPAR, Maria Dulce. Garotas de programa. Prostituição em Copacabana e identidade social. 2 ed. Rio de Janeiro: Jorge Zahar Editor, 1988.

LEITE, Elaine da. S.; MELO, Natália M. Uma nova noção de empresário:a naturalização do "empreendedor". Revista de Sociologia e Politica, Curitiba, v. 16 n.31, p. 35-47, nov. 2008.

MELO, Natália. M. SEBRAE e o Empreendedorismo: oriegem e desenvolvimento. Dissertação de mestrado. Sociologia. São Carlos, 2008.

ORTNER, Sherry. Poder e projetos: reflexões sobre a agência. In: GROSSI, Míram.; ECKERT, Cornélia.; FRY, Peter. Conferências e diálogos: saberes e práticas antropológicas. Goiânia: Nova Letra, 2006. p. 45-80.

SAINT-MARTIN, Monique de. Reconversões e reestruturações das elites: o caso da aristocracia na França. Analise Social, vol. 30, n. 143, p. 1023-1039, 1995.Acessado em 
18 jan. de 2016.

http://analisesocial.ics.ul.pt/documentos/1223389034F9vBA2bc9Cp29OZ5.pdf

SENNETT, Richard. A cultura do novo capitalismo. Rio de Janeiro: Record, 2006.

STANDING, Guy. O precariado. A nova classe perigosa. $1^{\circ}$ Edição; $2^{\circ}$ Reimpressão. ed. Belo Horizonte: Autêntica Editora, 2015.

VELHO, Gilberto. Projeto e Metamorfose.Antropologia das sociedades complexas. Rio de Janeiro: Jorge Zahar Editor, 1994.

VELHO, Gilberto. Individualismo e Cultura.Notas para uma antropologia da sociedade contemporânea. $7^{\circ}$ edição. Rio de Janeiro: Jorge Zahar Editor, 2004.

VELHO, Gilberto.; KUSCHNIR, Karina. Mediação, Cultura e Política. Rio de Janeiro: Aeroplano, 2001.

ZALUAR, Alba. A máquina e a revolta. As organizações populares e o significado da pobreza. 2ed. São Paulo: Editora Brasiliense, 1994.

ZELIZER, Viviana. La negociación de la intimidad. Buenos Aires: Fondo de Cultura Economica, 2009.

\section{Apêndice A}

Visão geral dos profissionais, ou seja, dos personals citados no texto. Em primeiro lugar, descreverei os seis informantes com os quais tive um acesso mais profundo e longo.

Alexandre, personal xamã : nasceu em São Paulo, está na faixa etária entre 55 e 60 anos, graduado em Psicologia (UFPR) e tem especializações em Teosofia, Xamanismo realizadas no exterior, além de ter estudado Université de Paix, na Bélgica. A família tem uma empresa no setor metal-mecânico em São Paulo.

Amadeu, personal dogwalker: nasceu em São Paulo, está na faixa etária entre 30 e 35 anos e estuda Veterinária ( UniRitter) pai e mãe são executivos e trabalharam em empresas nos EUA. Nasceu no Brasil e morou desde os 5 anos até os 23 nos EUA. 
Dora, personal organizer: encontra-se na faixa etária entre 50 e 55 anos, graduada em Arquitetura (Mackenzie), com especialização em Gestão da Qualidade Total. A sua família atua no ramo da construção civil em São Paulo.

Eduardo, personal trainer: está na faixa etária entre 50 e 55 anos, graduado em Educação Física (Unicamp) com diversas especializações nos EUA. A família (pai, tio e primo) tem uma clínica médica da qual ele também é sócio.

Madalena, personal friend: nasceu no interior do estado do RS, está na faixa etária entre 40 e 45 anos, tem curso superior em Administração (São Judas Tadeu), trabalha meio turno em uma empresa de contabilidade.

Marta, personal stylist: Esta na faixa etária entre 50 e 55 anos e foi a informante da dissertação de mestrado (2005 a 2006). A sua família atua no agronegócio, foi lojista (vestuário, acessórios e calçados) durante quase 20 anos, fez curso de consultoria de estilo na renomada escola de moda Parsons, Nova York, EUA.

$\mathrm{Na}$ sequência menciono os outros personals citados no artigo com os quais tive um acesso a informações pontuais, obtidas através de acompanhamento breve e de entrevistas.

Ágata, personal beauty: tem 43 anos, é formada em Estética pelo Senac/RS e trabalha na sua área de formação numa sala alugada por ela.

Andrielly, personal stylist: tem 33 anos, é graduada em Tecnólogo de Design de Moda/Senac, casada, sem filhos, marido trabalha em um banco do setor público. Há dois anos ela investe na sua formação de personal stylist e ambiciona viver desse oficio. No entanto, apesar de ser graduada na área ter cursado no Senac/SP o curso de personal stylist : consultoria em imagem, até agora não consegue se firmar como tal e sustentarse através dessa ocupação .Atualmente, também, trabalha na área de vendas.

Eugênia, personal organizer: tem 31 anos é graduada em Tecnologia de Gestão da Qualidade Uniasselvi/Iergs. Nos últimos quatro anos ela tem investido na sua formação de personal organizer, realizando cursos na área, além de frequentar os eventos que acontecem em São Paulo. Seu desejo é trabalhar somente essa atividade. Atualmente, também, trabalha como terceirizada numa empresa de promoção de produtos.

Felipe, personal trainer : tem 25 anos, é recém formado em Educação Física, ( Unilasalle), atua como personal trainer, de forma provisória em três academias e, ao mesmo tempo, estuda para concursos públicos e tem pretensões de cursar mestrado em Educação Física. 
Janice, personal stylist: tem 21 anos, é formada em Tecnólogo de Design de Moda/Senac e mora com os pais. Atua de forma provisória e esporádica como personal stylist em quanto estuda para concursos de nível de segundo grau, para ter uma renda estável e fazer outra graduação numa área que a prepare para passar em concursos públicos de nível superior.

José, personal husband: tem 35 anos, Técnico em Qualidade (Fundatec) e participou de vários cursos de qualificação do Senai ( hidráulico, eletricista, marcernaria). Ele sempre trabalhou na ferragem da família e é através da ferragem que acessa os clientes para a sua atividade de personal husband.

Renata, personal organizer: tem 32 anos, é bacharel em Direito (Anhanguera/Santo André), está na atividade de personal organizer de forma provisória, enquanto estuda para concursos públicos na sua área de formação.

Pedro, personal trainer : tem 36 anos é formado em Educação Física ( Unilasalle). Ele trabalha em algumas academias como personal trainer e a sua meta profissional é sustentar-se somente com esse trabalho sem a mediação das academias.

Tânia, personal décor: tem 54 anos é arquiteta (UniRitter) especializada em decoração de interiores e tem escritório localizado no bairro Moinhos de Vento.

Zuleica, personal assistent: Ela está na faixa dos quarenta anos, graduada em Relações Públicas (Fapa/UniRitter). Ela trabalha como promotora de eventos autônoma em quanto ainda não consegue se manter somente com a atividade de personal assistent.

Almir, personal invest: tem 41 anos e almeja trabalhar só como personal invest. Graduado em Ciências Contábeis (São Judas Tadeu), com especialização em Planejamento Financeiro (Unisinos), atua como consultor no Sebrae/RS e Senai. Atualmente está tentando se firmar como personal invest, exercendo essa atividade para a alguns empresários cujas empresas prestou serviços de consultoria financeira.

Kátia, personal organizer: tem 26 anos, é formada em Pedagogia EaD/Uniasselvi/Iergs, mora com os pais. Atua de forma transitória como personal organizer, enquanto estuda para concursos. Atualmente, também, trabalha meio turno como secretária em um escritório de arquitetura.

E por último descrevo os três clientes os quais tive acesso: 
Luan: é graduado em Engenharia da Computação em uma universidade federal, faixa etária entre 35 e 40 anos. Sempre trabalhou em empresas ligadas a área de tecnologia ${ }^{34}$, já fez dois MBAs no exterior um em gestão e outro em marketing digital e atua como Gerente de Projetos. Ele é oriundo do interior do estado do Rio Grande do Sul e sua família é produtora rural economicamente estável e com muitos contatos no meio político. Desde 2011 ele não trabalha mais com carteira assinada, pois a empresa na qual atua lhe fez uma proposta para que ele se Pejotizasse (constituísse uma empresa) e se convertesse em um dos tantos Gestores de Projetos da holding. Ele é bem apessoado, porte atlético, gosta de praticar esportes,viajar, tem gosto sofisticado, vida social intensa, conhece as marcas que estão na moda de todas as áreas, dinâmico, viaja muito a trabalho, pois tem equipes multidisciplinares que estão em vários países. A sua remuneração esta na faixa de $\mathrm{R} \$ 30.000,0$ a 40.000,00 incluindo os prêmios por metas alcançadas.

Narjara: está na faixa dos 35 a 40 anos, estudou Publicidade e Design Gráfico em universidade federal, trabalha como web designer, tem cursos de especialização na área de atuação e, atualmente, também atua na área de designer de games ou jogos digitais. Ela é uma pessoa sociável, de gostos sofisticados, de conversa agradável, gosta e prática de esportes radicais, como escaladas, paraquedismo e bungee jumping ${ }^{35}$. Em relação ao trabalho, tem um alto cargo gerencial em uma empresa de TI e a sua remuneração encontra-se na faixa de $\mathrm{R} \$ 25.000,00$ a $\mathrm{R} \$ 35.000,00$, ainda, trabalha com carteira assinada. Ela provém de uma família de posses do interior catarinense e seu trabalho exige que viaje muito para monitorar as suas equipes dentro e fora do Brasil.

Francisco: também atua na área de TI, tem um cargo de direção e trabalha com comercio eletrônico, é graduado em Engenharia Eletrônica, faixa etária de 50 a 55 anos e desde os anos oitenta trabalha com novas tecnologias de informação. Ele nasceu no norte do Brasil e já trabalhou em vários estados e no exterior acumula alguns MBAs, tem porte atlético gosta de praticar esportes, em particular natação e corrida. Tanto assim que já participou da corrida de São Silvestre em varias partes do mundo, bem

\footnotetext{
34 Empresas que atuam na área de Tecnologia e realizam um conjunto de atividades que fornecem soluções através de recursos computacionais que visam permitir a obtenção, o armazenamento, o acesso, o gerenciamento e o uso das informações. Exemplos :Google, Facebook, Apple, LinkedIn, T-Mobile, Salesforce, Yelp, Intel, Airbnb, BigData. Definição fornecida por Luan.

35 Conforme Narjara é uma pratica esportiva que consiste em saltar de uma altura de 25 a 30 metros num vazio amarrado aos tornozelos ou cintura a uma corda elástica.
} 
como já de algumas travessias a nado, nacionais e internacionais. A sua remuneração está em torno dos $\mathrm{R} \$ 50.000,00$, fora os prêmios por metas atingidas. Ele não trabalha de carteira assinada, tem uma empresa (pejotizado), mas é incluído nos benéficos da empresa na qual trabalha como qualquer empregado de carteira assinada, exemplo, usufrui o convenio médico, contribui para o fundo de aposentadoria e tem carro da empresa com motorista. Ele trabalha entre 10 a 12 horas por dia e viaja bastante, a trabalho, além de ter uma vida social intensa devido a sua ampla rede social.

Recebido 11/02/2020

Aprovado 10/04/2020 